\title{
平均・分散アプローチを活用した 最適落石災害対策計画
}

\author{
高木 朗義 1 ・倉内 文孝 2 ‘丸山 竜平3 \\ 1正会員 岐阜大学教授 工学部社会基盤工学科（†501-1193 岐阜県岐阜市柳戸1-1） \\ E-mail: a_takagi@gifu-u.ac.jp \\ 2正会員 岐阜大学教授 工学部社会基盤工学科（テ501-1193 岐阜県岐阜市柳戸1-1） \\ E-mail: kurauchi@gifu-u.ac.jp \\ 3 正会員 岐阜県県土整備部（干500-8570 岐阜市藪田南2-1-1） \\ E-mail: maruyama-ryuhei@pref.gifu.lg.jp
}

\begin{abstract}
我が国の山間地域では常に落石災害の危険にさらされている一方で，対策に用いることができる予算は 㛜しく，優先順位を決めて落石災害対策を行う必要がある。このような際に，期待被害額のみによる便益 は対策効果を過小評価していることが指摘されている. 本研究では, 平均・分散アプローチを援用するこ とで，所与の予算制約の下で災害リスクと対策後の損失額の不確実性の重み付き和を最小化する最適対策 戦略を決定する数理最適化問題を定式化する。斜面災害発生確率が独立と仮定した場合には，この問題は 二值整数線形計画問題（BILP） となる. 仮想データを用いて提案したモデルの挙動を確認すると共に, 岐 阜県飛騨圏域における落石災害対策計画に適用寸ることで，提案した手法の有用性を検証した。
\end{abstract}

Key Words : risk management, mean-variance approach, rock-fall disaster

\section{1. はじめに}

高度に発展した現代社会では，ますます災害時の損失 は大きくなっている. この理由は簡単でもあり難しくも あるのである; 人間や社会がより脆弱になっているので ある. 人間はより脆弱な地域に集中し，自然の耐災力を 低下させ，そして経済活動により環境破壊を進め，災害 危険性を高めている.このような中，我々はリスクとと もに生きていかなければならないことを認識し，より安 全な社会の形成のために，リスクを認識，評価し，そし てそれを政策に活かしていくことが重要である ${ }^{1)}$.

我が国の山間地域では，常に落石災害の危険にさらさ れている，岐阜県においても，いかに効率的に落石災害 対策を進めていくかが大きな課題となっている. 一方で, 対策に用いることができる予算は多くなく，合理的に落 石災害対策を行うことが求められている。 このような際 には，対策費用に対する効果，すなわち費用対効果に基 づき対策箇所の優先順位決定が行われることが多い.さ らに，その効果は落石災害の発生確率に災害発生時の損 失を乗じた期待損失が，対策を講じることでごの程度軽 減するかと定義することが多い，この際，災害が発生す れば甚大な被害が生じることがわかっていたとしてもそ
の災害発生確率が非常に小さく見積もられる場合, 期待 損失額としては小さくなってしまい，対策が後回しにな ることも考えられる. 特に, 災害発生後において, 「ひ とたび発生すれば被害が甚大であることがわかっている ならなぜ対策を優先しなかったのか」といった批判がし ばし生じる，このような批判は，災害発生の頻度には言 及しておらず，発生後の被害の大きさによるものといえ るだろう。すなわち，災害発生確率を加味した期待損失 だけでなく，その結果生じうる損失の大きさも加味した 評価が必要と考えられる.

本研究では，ひとたび災害が発生すれば甚大な被害を 生じる事象に対して優先性を付加するフレームワークを 構築し, 実務の現場においてしばし生じる期待損失軽減 による優先順位決定の課題を改善することを目的とする. そのために，平均・分散アプローチを適用することを提 案し，損失額の期待值と分散をパラメータ $\alpha$ 介して結 合することで，災害発生時の損失額の大きさを重視可能 な方法論を構築する. 所与の予算制約下での不確実性を 考慮した最適対策箇所の組み合わせを決定する最適化モ デルを構築するとともに, 岐阜県飛騨圈域における落石 災害対策計画に適用することで，提案した手法の有用性 を確認する. 
災害発生という不確実下でのプロジェクト便益におい て，被害軽減額の期待值を便益と捉えることには， Weisbrod ${ }^{2)}$, Bishop ${ }^{3)}$ をじめ多くの研究者が過小評価で あることを指摘しており，不確実性下の便益定義を Option Price とし, 評価する方法が提案されている ${ }^{4), 5)}$. また，小林・横松 のは，期待被害額による便益評価は， 家計が被った被害額が災害保険により完全にカバーされ る場合を想定したものであり，自然災害のような巨大 性・集合性を持つカタストロフ・リスクの場合，社会全 体で生じる被害を災害保険により担保できないことを指 摘し，相互保険と状況依存的証券を組夕合わせた災害保 険によりパレート最適な災害リスク配分を分権的に達成 することが可能であることを示した上で，カタストロ フ・リスクの軽減便益の測定手法を提案している. ここ で示した手法は，いずれも防災投資の前後での一般均衡 理論に基づき等価的偏差としてオプション価格を推定し ており，その推定においては一般均衡モデルを活用する ことが必須である. 一方，道路管理者が数ある災害仜険 地点における防災投資を考えるにあたり，対策の有無や その組み合わせごとにそれぞれ一般均衡状態を求めるこ とは現実的ではないと考える．対策の有無による効果が 加法的に表現できる方法論の構築が必要と考え, 本研究 では平均・分散アプローチの適用を検討することとする。 土木計画分野における平均・分散アプローチの適用例 として，まずは意思決定理論への適用を試みたものがあ げられる. 有馬ら ${ }^{7}$ は, 経路選択決定において平均・分 散モデルの適用を提案している．また，社会資本の資源 配分方法に適用した例として，大堀・原田 ${ }^{8)}$ は，職員の 業績率を確率変数と捉え, 業績率の期待值と標準偏差に 着目し，一定の期待業績率を確保しながらリスクを最小 化する，あるいはリスクを一定值に抑えながら業績率を 最大化する手法を提案しているものがある．本研究では， 災害リスクを確率変数と捉え, その平均と分散を考慮し た最適戦略を求める方法を提案する.

\section{2. 平均・分散アプローチに基づく最適化モデルの 構築}

\section{(1) 平均 ·分散アプローチの概要}

本研究では，金融工学などで活用されているポートフ オリオ最適化問題を援用する. 株式や債券などの証券投 資を行うとき，ポートフォリオ（複数の種類で構成され る組み合わせ）を組んで投資を行うことが一般的である. そして，投資家にとって最適なポートフォリオを求める 問題を一般的にポートフォリオ最適化問題と呼ぶ. ポー トフォリオ最適化は，以下の 3 とおりのいずれかで定式 化される ${ }^{9}$.

a) 投資家が要求するリターン尺度がある一定值以上
のもとでリスクを最小化する問題を解く.

b) 投資家が許容するリスク尺度の元でリターン尺度 を最大化する問題を解く.

c) リターン尺度とリスク尺度を用いて定義された関 数を最大化する問題を解く.

本研究では，この中の c)の中で特に一般的に用いられ ている平均・分散モデル ${ }^{10)}$ 用いた落石対策計画策定の ための手法を開発する. 平均・分散モデルでは, リター ン尺度とリスク尺度の重み付き和をもつて評価を行う。 なお，目的関数の形としては，ここで採用する平均・分 散の重み付き和に限定されているわけではなく，リター ン尺度とリスク尺度を個別に取り扱う多目的計画法とし， パレート最適解を求める方法 ${ }^{11}$ なども考えられるが，こ こではモデルの簡便性を重視した。また，リターン尺度 を対策による損失額の期待值の軽減分（以下期待值軽 減），リスク尺度を対策による損失額の分散の軽減分

(以下分散軽減）とする. 損失額の分散を考慮すること で，損失額の組み合わせと各斜面を対策することによっ て軽減される損失額の総和のバラツキを表し，その損失 額の分散を対策効果の不確実性として算出することが可 能となる.

\section{（2）対策効果の定義}

本研究では，ある被災が生じる確率と被災した場合の 期待值軽減分と分散軽減分の重み付き和を目的関数とし て設定する．計算にあたっては，落石災害が発生する年 確率は，斜面ごとに独立な事象としてとらえることとし た。また，ある瞬間に同時に2つ以上の災害が発生しな いものとし，1 年に複数の斜面で被害が発生した場合の 年間損失額は各斜面で定義される損失額の和で示される こととする.なお，現実には豪雨発生時などにおいて複 数の落石が近辺で同時に発生することは多々あり，なお かつこの場合の損失額は単純に単一斜面において災害が 発生したときの損失額の和とはならないため, これらの 仮定が適切とはいいら゙らい。一方で，落石災害発生確率 に相関性を考慮する場合，計算が非常に複雑になってし まう。そのため，ここでは相関性の考慮，あるいは独立 性を確保するための工夫などに関しては今後の課題と位 置づけることとし, 各落石災害の発生は独立事象として 取り扱うこととする.

今, 斜面 $i$ における年落石災害発生確率を $p_{i}$, 斜面 $i$ における落石による社会経済的損失を $d_{i}$ とする. このと き，落石災害年発生確率はベルヌーイ分布に従うと見な すことができ，それを用いて落石災害の年間損失額の平 均 $e_{i}$ および分散 $v_{i}$ は次のように記述できる.

$$
e_{i}=p_{i} d_{i}
$$




$$
v_{i}=p_{i}\left(1-p_{i}\right) d_{i}^{2}=p_{i} d_{i}^{2}-\left(p_{i} d_{i}\right)^{2}
$$

また，斜面ごとの災害発生確率は独立であると仮定し ていることから，全ての斜面に対する現状の年間損失額 の期待值 $E_{0}$ および分散 $V_{0}$ は各斜面に関する平均および 分散の和として次のように記述できる.

$$
\begin{gathered}
E_{0}=\sum_{i} e_{i}=\sum_{i} p_{i} d_{i} \\
V_{0}=\sum_{i} v_{i}=\sum_{i}\left\{p_{i} d_{i}^{2}-\left(p_{i} d_{i}\right)^{2}\right\}
\end{gathered}
$$

今，ある年度における対策斜面の集合を要素数 $N$ の 二值変数べクトル $\mathbf{x}\left(=\left(x_{1}, x_{2}, \ldots, x_{N}\right)^{T}\right.$, 斜面 $i$ を対策する なら 1，しないなら 0) で表現するとしよう。ある年度 の対策斜面が $\mathbf{x}$ で表現されるとき，年間損失額の期待值 軽減分 $\Delta E[\mathbf{x}]$ および分散軽減分 $\Delta U \mathbf{x}]$ は, 次のように記述 できる.

$$
\begin{gathered}
\Delta E[\mathbf{x}]=\sum_{i} p_{i} d_{i}-\sum_{i}\left(1-x_{i}\right) p_{i} d_{i} \\
=\sum_{i} x_{i} p_{i} d_{i} \\
\Delta V[\mathbf{x}]=\left\{\sum_{i} p_{i} d_{i}^{2}-\sum_{i}\left(p_{i} d_{i}\right)^{2}\right\} \\
-\left\{\sum_{i}\left(1-x_{i}\right) p_{i} d_{i}^{2}-\sum_{i}\left(1-x_{i}\right)\left(p_{i} d_{i}\right)^{2}\right\} \\
=\sum_{i} x_{i}\left(p_{i} d_{i}^{2}-\left(p_{i} d_{i}\right)^{2}\right)
\end{gathered}
$$

\section{(3) 最適化問題の定式化}

本研究では，所与の年予算制約の下で，損失額の平均 と分散の重み付き和を最小化する問題を解くこととする. 式(5), (6)より，損失額の期待值および分散は対策ベク トル $\mathbf{x}$ の線形結合となっていることから，この問題は二 值整数線形計画問題として次のように定式化できる.

$$
\operatorname{Max} z=\Delta E[\mathbf{x}]+\alpha \Delta V[\mathbf{x}]
$$

Subject to

$$
\sum_{i=1}^{N} c_{i} x_{i} \leq \text { Budget }
$$

ここで, $c_{i}$ : 斜面 $i$ の対策費用， $\alpha$ : 分散の重みを表すパ ラメータ, Budget : 年間の落石対策予算.

式(7)より，不確実性の価值を示すパラメータ $\alpha$ 介し， 不確実性を考慮することとなる。 この落石対策計画策定 の最適化問題を解くことで，平均と分散の重みの付け方 によって対策される斜面の変化にどういった特徵がみら れるのかを分析することが可能である.

\section{(4) 計算方法}

本研究では, 2.(3)で定式化された問題を繰り返し解く ことで，年度ごとの最適対策箇所を決定することとする. 対策年度 1 年目について，対策を行うべき全斜面を検討
対象として計算を行う。得られた結果から, 対策年度 1 年目に対策する斜面を全斜面の中から取り除き, 残った 斜面で同様な計算を 2 年目， 3 年目と続け，この計算を 全ての斜面に対策が行われるまで繰り返し行う。また, 求解にあたり, Matlab を用い, 整数計画問題を解く高速 アルゴリズムである Gurobi ${ }^{12}$ を Matlab から呼び出すこと にした，後述するケーススタディにおいては，1,607 カ 所の斜面を対策候補地点として計算を行った場合でも, 全斜面に対する最適対策の計算は 1 秒程度で行うことが できる.

\section{3. 仮想データを用いた挙動確認}

提案したモデルの挙動を確認するために, 斜面数 20 の仮想地域を想定し，モデルを適用した。ここで設定し た斜面の災害発生確率 $(p)$ および災害発生時の損失額 (d) ）およびその積 $(p \times d)$ で得られる損失額の期待 值は表-1 のとおりである. なお，斜面の ID は損失額 $d$ の小さい順に並べている．対策費用は全斜面一律 500 万 円とし，1000 万円を予算制約とした．ここでは，損失 額の期待值のみによる最適化 $(\alpha=0.0)$ と損失額の分散 が支配的になるケース（ $\alpha=1000 ）$ の計算過程を示し，そ の違いを考察する. 図-1に各ケースにおける対策年度と 対策箇所の関係を，図-2にそれぞれのケースにおける 期待值および分散の変化を示す. 図-2 における右上の 点が初期状態であり，そこから毎年選択された対策を施 すことで平均值及び分散值が減少していく様子を示して いる.この計算では, 10 年分の計算を行うことです心゙ ての斜面の対策を終え, 損失額の期待值および分散はゼ ロとなる. 図-1 より，損失額の期待值と分散を考慮し た場合とでは，年度ごとに対策斜面に違いがあることが わかる. 具体的には, 期待値のみを考慮する場合には, 損失額の期待值が大きな斜面 10,11 を初年度に，その 後もこの順位に従って対策を講じている. 一方で, 分散 による最適化では，対策斜面の ID が大きい，すなわち 損失額が比較的大きな斜面を優先する傾向にある. また， 図-2より，年を追うごとの期待值および分散の残存率 も異なる．期待值のみを考慮する場合（図中青線）には, 1 年目でおよそ $15 \%$ の期待值が減少するが，分散は $10 \%$ 強しか減少しない。一方で, 分散を重視する場合 (図中 緑線）には， 1 年目に分散が $20 \%$ 程度減少されるが，期 待值は $10 \%$ 程度である. このように， $の$ 設定によって， リターン尺度あるいはリスク尺度の重み付けが可能とな っており，その結果として異なる対策戦略が策定される ことが確認できる. 


\section{4. 岐阜県飛騨圏域における落石災害対策の評価 と年次計画の策定}

\section{(1) 対象地域の概要}

提案したモデルを，岐阜県飛騨圈域における斜面に適 用した。岐阜県飛騨圈域には山間地域が多く, 落石の危 険がある斜面が 1,607 箇所と非常に多い.このような現 状の中，落石災害対策を早急に行う必要があるが，国や 他の自治体と同様に，岐阜県でも公共事業費の削減や県 職員の削減などの影響により，全ての斜面に対して同時 進行的に落石災害対策を講じることは困難な状況にある ことから合理的な落石対策が求められている.

検討に用いる各斜面の災害発生確率および損失額につ

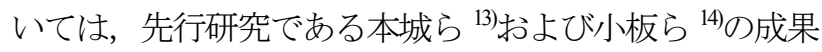
のものである.

\section{(2) 各斜面の優先順位の考察}

式(7)の目的関数は，斜面対策実施の有無を表現する $x_{i}$ で分離することが可能であるため，その目的関数に対す る係数が大きければより対策優先度の高い斜面であると 考えることができる，そのため，まずは各斜面に関する 目的関数の係数を元に，パラメータ 00 值ごとに斜面対 策の優先順位を求めた. パラメータ $\alpha$ を変化させること で，損失額の期待值と分散の $2 つ の$ 評価尺度の比重を変 えた場合の評価を行うことができる． $\alpha=0.0$ ならば損失 額の期待值のみの評価， $\alpha=1000$ ならばほぼ損失額の分散 のみを考慮した評価となる．図-3に，重みごとの対策優 先順位の上位 20 斜面に関して，対策の優先順位の変化に 同じような特徵を持つ斜面がいくつか存在した，それら の斜面をグループ分けしたものを示す. 分析の結果より 損失額の期待值で評価を行った場合と損失額の分散で評 価を行った場合では，対策の優先順位が異なることがわ かる.また，パラメータ ねよって対策の優先順位が変 化していくこともわかる．このことより，社会経済的損 失の期待值と分散を考慮した評価によって，対策を行う 斜面の優先順位が変化するといえる. 次に, グループ分 けされた斜面を，縦軸に落石の発生確率，横軸に落石に よって生じる社会経済的損失（万円）を取ったグラフを 図-4に示寸．グラフには年間損失額の期待值が一定とな る曲線（等損失期待値曲線）も併せて示寸.

「常に対策優先度が高い斜面」と判断されたグループ 1 の斜面を見てみると, グラフの右側に点がプロットさ れており, なおかつ等損失期待値曲線と比較してもより 右上の方向，つまり損失期待值も非常に大きいことがわ かる. これより，災害発生時の損失額が他の斜面と比較 して大きく，なおかつ期待損失額も大きい斜面であるた め，社会経済的損失を計算過程に含む期待值・分散どち らの評価の場合でもこれらの斜面が常に上位となってい
表-1 災害発生確率と損失額

\begin{tabular}{|c|c|c|c||c|c|c|c|}
\hline $\mathrm{D}$ & $p_{i}$ & $d_{i}$ & $p \times d$ & $\mathrm{ID}$ & $p_{i}$ & $d_{i}$ & $p \times d$ \\
\hline 1 & 0.95 & 100 & 95 & 11 & 0.45 & 4100 & 1845 \\
\hline 2 & 0.9 & 500 & 450 & 12 & 0.4 & 4500 & 1800 \\
\hline 3 & 0.85 & 900 & 765 & 13 & 0.35 & 4900 & 1715 \\
\hline 4 & 0.8 & 1300 & 1040 & 14 & 0.3 & 5300 & 1590 \\
\hline 5 & 0.75 & 1700 & 1275 & 15 & 0.25 & 5700 & 1425 \\
\hline 6 & 0.7 & 2100 & 1470 & 16 & 0.2 & 6100 & 1220 \\
\hline 7 & 0.65 & 2500 & 1625 & 17 & 0.15 & 6500 & 975 \\
\hline 8 & 0.6 & 2900 & 1740 & 18 & 0.1 & 6900 & 690 \\
\hline 9 & 0.55 & 3300 & 1815 & 19 & 0.05 & 7300 & 365 \\
\hline 10 & 0.5 & 3700 & 1850 & 20 & 0.025 & 7700 & 192.5 \\
\hline
\end{tabular}

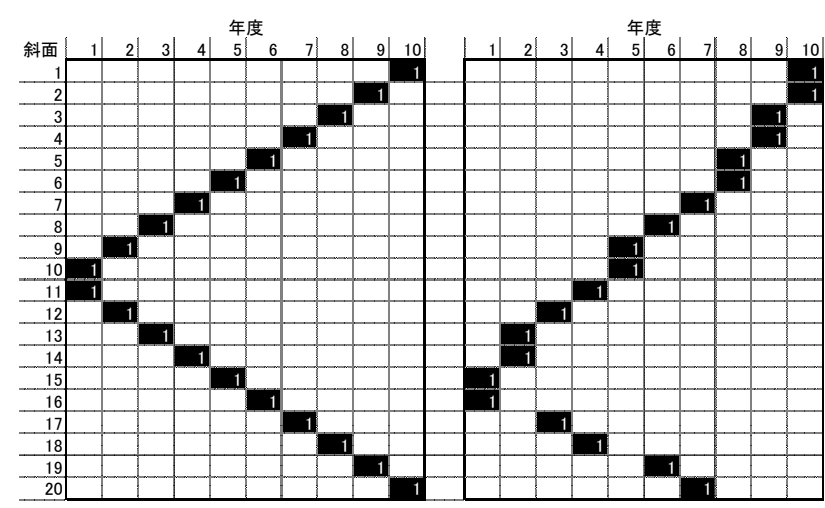

（a）期待値による最適化 $(\alpha=0$

(b) 分散による最適化 $(\alpha=1000)$

図-1 年ごとの対策箇所

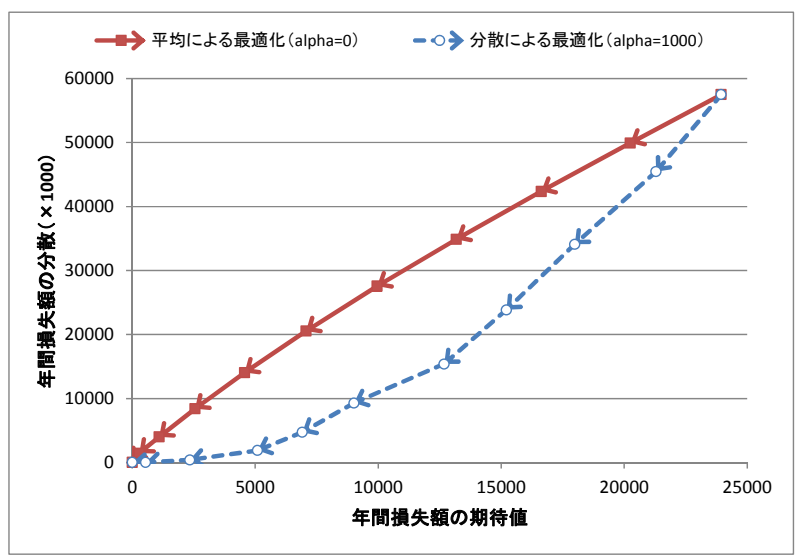

図-2 パラメータ・の違いによる年間損失額の 期待值および分散の軽減過程

るといえる。「期待值を重視すると対策優先度が高くな る斜面」であるグループ 2 の斜面は，グラフの左上側に 位置しており, 落石の発生確率が高いという共通点があ る. グループ 2 の斜面は，分散を考慮していくに従い対 策優先順位が低くなっていく.つまり, 社会経済的損失 はそれほど大きくないが，落石発生確率が高い斜面群で あり，社会経済損失の期待值を重視するとこれらの斜面 の対策も対象になる。一方，「分散を重視すると対策優 先度が高くなる斜面」と判定されたグループ 3 の斜面に 関しては，確率の值はそれほど大きくはないが，社会経 済的損失の值が比較的大きな斜面であり, グループ 2 の 
斜面とは逆の性質を示していることがわかる.グループ 4 の斜面に関しては，グループ 2 とグループ 3 の斜面の ちょうど中間の性質をもった斜面であるといえる．グル ープ 2〜4 に着目してみると，これらのグループは同じ ような等期待損失額曲線上にプロットされていることが わかる.つまり,グループ 2〜4 の斜面は同じような損 失額の期待值をとる. このような場合，分散を考慮して いくことで損失額の大きい斜面が選択される傾向にある. 最後に，グループ 5 は，等期待損失額曲線を見ればわか るように，期待損失額は他のグループと比較して小さい． しかしながら，社会経済的損失額が比較的大きいため, 特に分散の值を大きくすると相対的に対策優先度が高く なる斜面といえる. 以上から，提案したモデルでは， $\alpha$ の值を変化させることによって，損失額の期待值だけで なく損失額の分散を考慮することができ，損失発生の不 確実性も考慮した対策優先順位決定が可能であることが 確認できた.

\section{(3) 最適化計算結果の分析}

制約条件とパラメータの值を与え，各年度における対 策箇所の最適化を全斜面の対策が終了するまで行った. 制約条件として与える年間の落石対策予算は, 平成 21 年度の岐阜県の落石対策予算（1,769 百万円）と寸る. 各パラメータ $\alpha$ ごとに, 本研究で提案した最適化モデル を用いて計算し，対策年度ごとに残存している期待值と 分散を求めた。 その結果得られた計算過程を図-5 に示 す. 図-5 は，図-2 と同様に右上の点から対策を行うこ とで期待リスク及び分散が減少していく様子を示寸．損 失額の期待值のみによる最適化 $(\alpha-0.0)$ と損失額の分 散に基づく最適化（ $\alpha=1000 ）$ では計算結果に違いが生じ る.これは，仮想データで試算を行った結果と同様に， 各ケースにおいて選択される斜面が異なることから，計 算過程が評価尺度によって異なることを示している。ま た， $\alpha=0.0001$ の場合には，その中間的な位置づけになっ ていることがわかる，なお，仮想データによる計算結果 ほど，実データに基づく最適化では各尺度による差はみ られなかった。この理由を探るために，各斜面について の災害発生時の損失額と災害発生確率をそれぞれ 250 （万円）および 0.001 刻みで集計し，その頻度を集計し コンター図として示したものを図-6に示寸. 図中紫で 示されているところ（例えば(2250, 0.007)）は，災害発生 時の損失額が 2250〜2500（万円），災害発生確率が 0.007 0.008（/年）である斜面が 30〜40 箇所あること を示している，この図をみても明らかなように，災害発 生確率がおよそ 0.007 であり，災害発生時の損失額が 250 （万円）以下，1000（万円）程度，2250（万円）程 度のあたりにデータが集中していることが確認できる. 斜面ごとの落石発生確率の值や対策費用が類似した斜面

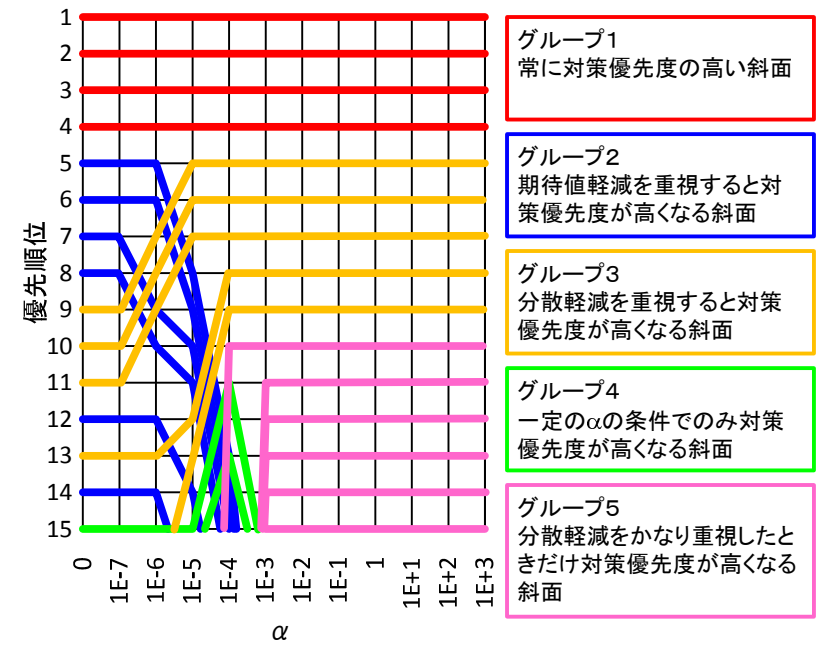

図-3 各斜面の対策優先順位の変移

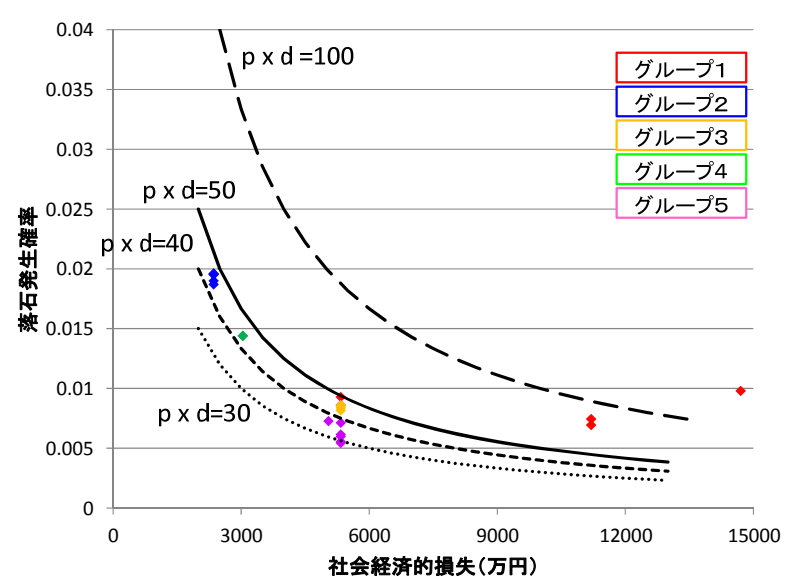

図-4 各グループの特性比較

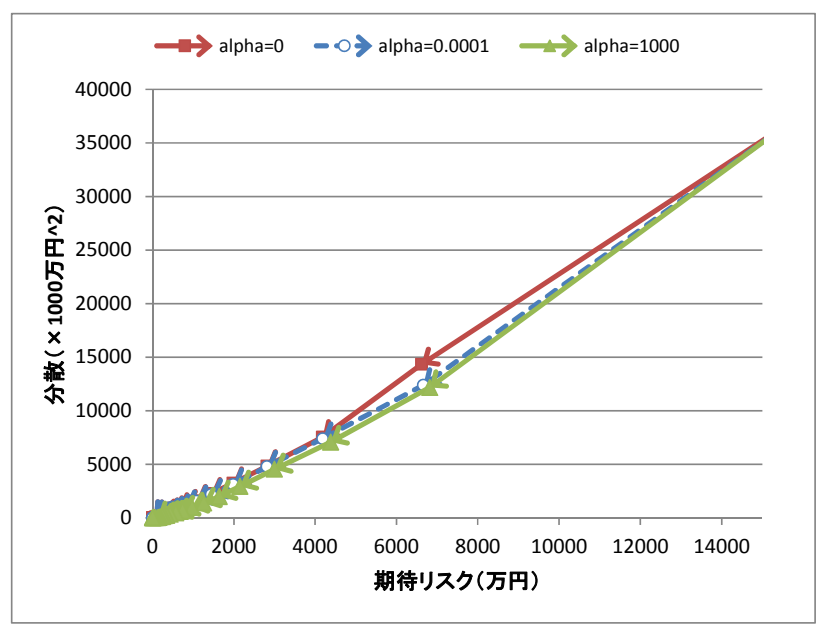

図-5 年間損失額の期待值および分散の軽減過程

が多く存在したため，期待值軽減分のみの評価と分散軽 減分のみの評価において，大きな違いが生じなかったの ではないかと推察される. 


\section{5. 実用化に向けての課題検討}

\section{（1）斜面の被災確率の独立性に関して}

2.(2)にも述べたとおり，本研究では各斜面の災害発生 確率は独立と仮定して計算を進めた，独立性を仮定する ことで簡単な定式化が可能となり，対策箇所が多くとも 高速に最適解が求められることが明らかとなった。一方 で，現実には豪雨発生時などにおいて複数の落石が近辺 で同時に発生することは多々あり，なおかつこの場合の 損失額は単純に単一斜面において災害が発生したときの 損失額の和とはならないため，これらの仮定が適切とは いえない，そのため，独立性が担保できるような工夫が 必要といえるだろう.

その方法としては，例えば過去の被災履歴を用い，災 害が同時発生する可能性が高い斜面群をグルーピングさ せ，同一グループ内の斜面群の災害は同時生起を，グル ープ間の災害発生に関しては独立と仮定することなどが 考えられる. 岐皁県では, 最近の斜面災害履歴は全て GIS 上でデータベース化されている. このようなデータ を活用することで，上記のようなグルーピングが可能で はないかと考えられる。

\section{（2）パラメータ $\alpha の$ 決定方法に関して}

本研究では，被害発生の不確実性に着目し，平均・分 散アプローチを用いることで災害発生確率が小さくとも 発生時の被害額が大きい事象により重きをおいた対策が 可能となる最適化モデルの構築を行っている. 前章まで の分析にて，モデルは想定通りの挙動を示していること が確認されたものの，本モデルを適用する際に重要な役

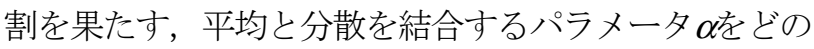
ように決定寸るかに関しては確たる基準はない，そのた め, ここでは $\alpha$ 決定するための試案を検討する.

本研究では, 各斜面の災害発生は独立事象であること を仮定している．この仮定により，災害発生の期待值お よび分散が式(3)，(4)のような簡単な式で示されること が明らかとなった．災害損失額の期待值および分散が明 らかになっていることから，もしその分布形がわかれば， 例えば $x \%$ の確率で生じる損失額をより小さくする，あ るいは $y$ 円以上の損失が生じる確率を最小にする，とい った目的を元に最適な $\alpha$ を求めることも可能ではないだ ろうか. このために，さらに，「各斜面の災害発生確率 はほぼ等しい」という仮定をおく，もちろん厳密には災 害発生確率はばらついているが，このように仮定するこ とで中心極限定理を用いることが可能となり，損失額の 分布は，災害損失額の期待值及び分散をそれぞれ平均, 分散にもつ正規分布に従うといえる．次に， $\alpha$ を決める ための基準として，「所与の損失額の発生確率が最小之 なる $\alpha\rfloor$ を求めることを考える. そして所与の損失額と

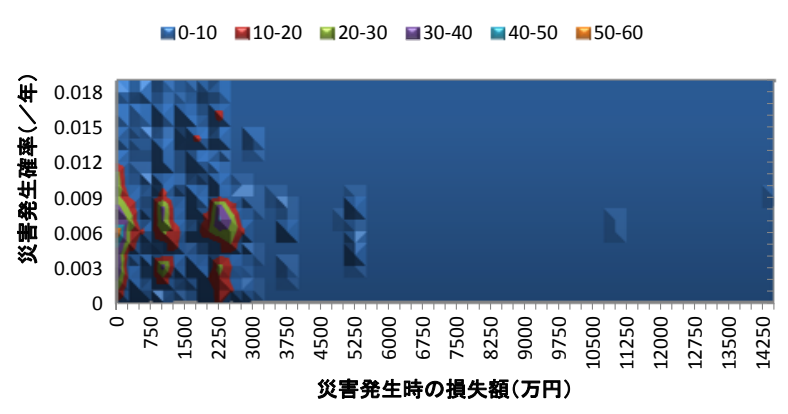

図-6 災害発生時の損失額と災害発生確率

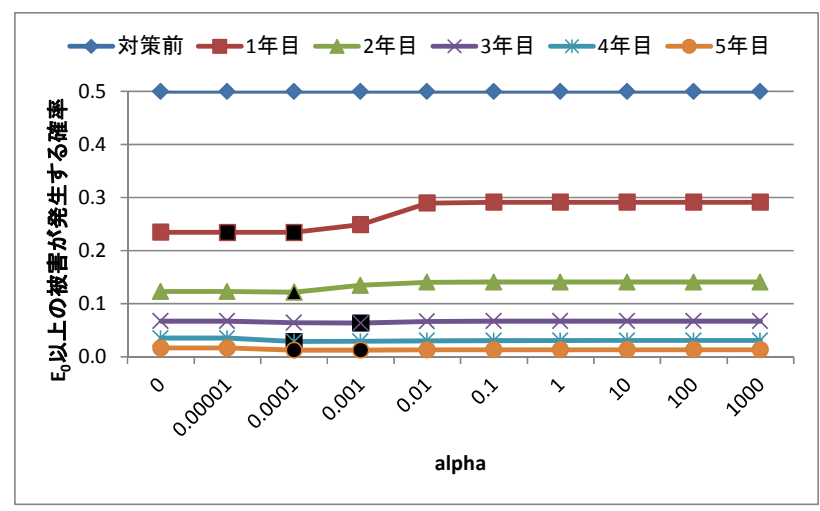

図-7 異なるdにおける対策前の期待損失以上の 損失が生じる確率の推移

して，例えば「対策前の損失額の期待值」とし，これ以 上の損失が発生する確率を最小にする $\alpha$ を求めることが できるだろう。

計算例として，4.で示した斜面データについて，予算 制約を300（百万円）とし， $\alpha$ を0.00001から10倍ずつ1000 まで変化させた場合と， $\alpha=0$ 場合の合計10ケースにつ いて，計算開始（0年目）から5年目までの対策前の損失 額の期待值 $E_{0}$ より大きな被害が生じる確率を計算した結 果を図-7に示寸，なお，図中黒いプロットにしているの が各年において最小の確率をとった の值を表している。

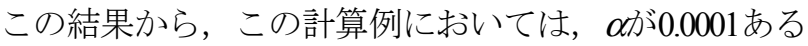
いは0.001の場合において対策前の期待損失以上の被災 を生じる確率をより小さくすることができるようである. なお，この計算を進めていけば最終的にこの確率はゼロ となることから，本来ならば毎年最適な $\alpha$ を選択してい く必要があるだろう。この点については今後の検討課題 としたい.

さらに，正攻法としてこの問題を記述するのであれば, $E(\mathbf{x})$ および $(\mathbf{x})$ を介して未知変数 $\mathbf{x}$ の関数として位置づけ られる,「平均 $E(\mathbf{x})$, 分散 $V(\mathbf{x})$ に従う正規分布について, 損失額が $E_{0}$ を回る確率」を目的関数とする必要がある。 この場合，目的関数が正規分布の累積分布関数となる. 今回活用した高速な求解アルゴリズムを適用することが 不可能となり，遺伝的アルゴリズムのようなヒューリス ティック手法を用いる必要性があるといえる。これにつ 
いても今後の検討課題に位置づけたい.

\section{6. おわりに}

本研究では，落石災害対策の対策計画策定を行うため の指標を作成すること目的として，平均・分散アプロー チを援用し，所与の予算制約の下で，災害リスクと対策 後の損失額の不確実性の重み付き和を最小化する数理計 画モデルを構築した. 本研究で提案する手法の特徵は, 各対策による分散低減効果を独立に取り扱うことが可能 である点である．最適化問題は，二值整数線形計画問題 として表現することができ，その最適化問題を解くツー ルとして，Matlabと Gurobi を活用することで高速に解を 求めることができ，実用性が高いことを示した。まずは， 提案した最適化モデルを斜面数 20 の仮想斜面データに 適用し考察を加えた。 その結果，損失額の期待值とその 分散の重みによって対策優先順位が異なること，分散を 考慮するとより被害額が大きな斜面の優先度が高まる傾 向にあることが明らかとなった．また，岐阜県飛騨圈域 への適用結果より，1,600 力所程度であれば十分実用的 なスピードで解を求めることが可能であることが確認さ れた。 さらに実用化に向けて，被災確率の独立性の担保 のための工夫および期待值と分散をつなぐ重み 0 設定 方法についても検討を加えた．今後の課題としては，適 用範囲の拡大や他の評価指標との組み合わせの検討，災 害発生確率の独立性担保の検討，経年変化の考慮などが あげられる。

謝辞: 本研究は，文部科学省特別教育研究経費「リスク に基づくアセット総合マネージメントによる社会基盤の 戦略的整備意思決定に関寸る研究（平成21～23年），研 究代表者 : 本城勇介岐阜大学教授」および平成22年度科 学研究費補助金（基盤研究(B), 課題番号 : 21360243, 研 究課題名 : 社会的費用を考慮した社会資本アセットマネ ジメントに基づく地域リスクガバナンス, 研究代表者 : 高木朗義）の成果の一部である。ここに，RM研究プロ ジェクト研究会にて貴重な意見をいただいた関係者の
方々に感謝申し上げたい.

\section{参考文献}

1) UNISDR: Living with risk: a global review of disaster reduction initiatives, 2004.

2) Weisbrod, B. A.: Collective-Consumption Services of Individual-Consumption Goods, Quarterly Journal of Economics, Vol. 78, pp. 471-477, 1964.

3) Bishop, R. C.: Option Value: an Exposition and Extension, Land Economics, Vo. 58, No. 1, pp. 1-15, 1982.

4) Graham, D. A.: Cost-Benefit Analysis Under Uncertainty, American Economic Review, Vol. 71, pp. 715-725, 1981.

5) 高木朗義, 森杉壽芳, 上田孝行, 西川幸雄, 佐藤 尚：立地均衡モデルを用いた治水投資の便益評価手 法に関する研究, 土木計画学研究・論文集, Vol. 13, pp. 339-348, 1996.

6) 小林潔司，横松宗太：カタストロフ・リスクと防災 投資の経済評価，土木学会論文集，No.639/IV-46, pp. 39-52, 2000.1.

7) 有馬和輝, 安東直紀, 谷口栄一, 山田忠史 : 道路齐 ットワークにおける所要時間の平均と分散を考慮し た最適経路決定手法に関する研究, 土木計画学研 究・講演集, Vol. 39, CD-ROM, 2009.

8) 大堀勝正, 原田邦彦: 社会資本の経営資源配分手法 に関する研究，（株）建設技術研究所 国土文化研 究所, 2010 年度年次報告, pp. 33-40, 2010 .

9) 枇々木規雄, 田辺隆人 : ポートフォリオ最適化と数 理計画法, 4, 朝倉書店, 2005 .

10) Markowitz, H.: Portfolio Selection, The Journal of Finance, Vol. 7, No.1, pp. 77-91, 1952.

11) 三澤勉，有村幹治，田村亨：道路ネットワークにお ける維持管理支援モデルの構築, 土木計画計画学研 究・講演集, Vol. 29, CD-ROM, 2004.

12) Gurobi Optimization ホームページ (http://www.gurobi.com/) 2013/3/14 アクセス.

13）本城勇介，町田裕樹，森口周二，原隆史，沢田和秀， 八嶋厚：岐阜県飛騨圈域を対象とした道路斜面危険 度評価，土木学会論文集 C (地圏工学)，Vol. 67, No. 3, pp. 299-309, 2011.

14）小板宏彰, 高木朗義, 倉内文孝, 北浦康嗣 : 道路途 絶による社会経済損失を考慮した斜面災害リスク評 価モデル, 土木計画学研究・講演集, Vol. 41, CDROM, 2010.

（2013. 3. 27 受付） 


\title{
OPTIMAL COUNTERMEASURE PLANNING AGAINST ROCK-FALL DISASTER USING MEAN-VARIANCE APPROACH
}

\author{
Akiyoshi TAKAGI, Fumitaka KURAUCHI and Ryuhei MARUYAMA
}

Mountainous areas in Japan has been exposed at the risk of rock-fall disaster. On the other hand, since the budget expensable for countermeasures against such disasters are limited, priority of the slopes at a risk of rock-fall should be discussed. In such situation, it is common to evaluate the priority of the site by cost-benefit-ratio and the benefit of the countermeasure is evaluated by the reduction of the expected economic loss. Much of researches however have pointed out the limitation of the evaluation only by the reduction of expected economic loss. This study formulates a mathematical programming problem to find an optimal strategies by minimising the weighted sum of the reductions of both expected economic loss reduction and the variance of the loss considering the budget constraints. We showed that the reduction of variance for each site is separable and the proposed model can be formulated as binary integer linear programming problem (BILP), if the occurrence probability of each slope is independent. The proposed model is first applied to the small network to see the performance, and then is applied to plan the optimal countermeasure planning of rock-fall disaster in Hida region of Gifu Prefecture. The result suggest the advantage of the proposed method. 